\title{
Effects of lactulose and lactitol on protein digestion and metabolism in conventional and germ free animal models: relevance of the results to their use in the treatment of portosystemic encephalopathy
}

\author{
Susan P Bird, D Hewitt, B Ratcliffe, M I Gurr
}

\begin{abstract}
Protein digestion and metabolism have been studied in laboratory rats and miniature pigs to investigate the mechanisms of action of lactulose and lactitol when used in the treatment of patients with portosystemic encephalopathy. Lactulose $(\beta$ - D - galactopyranosyl - $(1 \rightarrow 4)$ $\beta$-D-fructofuranose) and lactitol ( $\beta$-Dgalactopyranosyl-( $\rightarrow 4)$-D-glucitol) increased the excretion of nitrogenous material in the faeces and decreased nitrogen excretion in the urine in a similar degree to that reported for human patients. In studies with germ free rats given lactulose no such effect was observed, suggesting that, for lactulose at least, these effects are mediated by the gut flora. Measurement of the $\alpha-, \varepsilon$-diaminopimelic acid content of the faeces confirmed that the enhancement of faecal nitrogen was due to an increased contribution from bacteria. The similarity in the results for lactulose and lactitol suggests that, from the perspective of protein metabolism, lactitol acts in a similar way to lactulose in the treatment of portosystemic encephalopathy.
\end{abstract}

Lactulose $\quad(\beta$-D-galactopyranosyl- $(1 \rightarrow 4)-\beta$-Dfructofuranose) has been used in the treatment of portosystemic encephalopathy, a common complication of cirrhosis of the liver, ever since the pioneering experiments of Bircher et al. ${ }^{1}$ Its action is not fully understood, however, but several hypotheses have been suggested, all of which focus mainly on events in the lower gut. Conn and Lieberthal have listed five theories ${ }^{2}$ : bacteria ferment lactulose to organic acids, and the acidity produced encourages a more favourable gut flora; this acidity, and the osmotic effects of lactulose, have beneficial cathartic effects; the acidity inhibits production of ammonia by bacteria; the acidified luminal contents trap ammonia; lactulose stimulates bacterial growth and thereby the incorporation of luminal ammonia, and possibly ammonia from body tissue, into bacterial protein.

There is evidence from animal studies that any carbohydrate which reaches the lower gut has a considerable stimulatory effect on bacterial activity and growth, and hence on the quantity and type of faecal nitrogen. ${ }^{3}$ Lactulose is not hydrolysed by human gut enzymes ${ }^{4}$ and as it is not absorbed in the small intestine ${ }^{2}$ it reaches the lower gut. In patients with cirrhosis there is increased faecal nitrogen output when lactulose is given ${ }^{5}$ and this may be important in understanding its action. Mason has suggested that the use of lactulose in the treatment of portosystemic encephalopathy may depend on it providing an energy source for bacteria in the lower gut, and he suggested some alternatives which may be superior. ${ }^{6}$ Such bacterial growth uses the nitrogenous components of the luminal contents which would otherwise be absorbed into the systemic circulation, overloading the body's capacity to metabolise them, and leading to the neurological effects that characterise portosystemic encephalopathy. ${ }^{2}$

Lactulose syrup has to be prescribed in such large amounts (30-150 $\mathrm{ml}$ or more, equivalent to 20-100 $\mathrm{g}$ lactulose) that it can be regarded as a dietary supplement rather than a drug, but it is by no means ideal as a food ingredient. Substances with good functional properties would be attractive to doctors and the recently introduced crystalline lactulose may be preferable. ${ }^{7}$ There has been considerable interest in the use of lactitol ( $\beta$-D-galactopyranosyl- $(1 \rightarrow 4)$-D-glucitol) as an alternative for treating portosystemic encephalopathy because it is palatable and it may be as effective as lactulose syrup..$^{8-12}$

We have recently reported nutritional balance studies using the laboratory rat and the Göttingen miniature pig in which the energy values of lactulose and lactitol were determined. ${ }^{13}$ A further objective of that work was to establish the precise effect of lactulose in the diet on the routes of excretion of nitrogen since Conn and Lieberthal $^{2}$ suggested that this might explain its efficacy in the treatment of portosystemic encephalopathy. The studies on the laboratory rat were extended to elucidate the role of the gut flora. The effect of lactulose syrup on the bacterial component of faecal mass was assessed from the quantity of $\alpha$-, $\varepsilon$-diaminopimelic acid in the faeces. This precursor of lysine is not present in animals and is only found in appreciable quantities in some bacteria. Thus, this unusual amino acid can serve as a crude indicator of bacterial mass. In a further experiment the effect 
of lactulose syrup in germ free rats was studied. Clearly, if the mechanism of action does involve the gut flora then lactulose should be without effect in the absence of bacteria.

\section{Methods}

\section{STUDIES WITH LABORATORY RATS AND MINIATURE} PIGS

Conventional miniature pigs of the Göttingen strain, aged 11 weeks, and laboratory rats, aged 6 weeks, from the laboratory colony of barriermaintained, conventional Lister Norwegian hooded rats, were used in nutritional balance experiments. In one experiment 6 week old germ free and conventional rats of the Fisher strain were used. Details of procedures with conventional animals have been published elsewhere. ${ }^{13}$ The same type of metabolism cage was used for conventional and germ free rats, the latter inside Trexler type flexible plastic film isolators. ${ }^{14}$ All the rats were derived from the laboratory's small breeding colony of germ free animals, half of each litter being removed from the isolators at weaning to an animal room where they were conventionalised by dosing with a suspension of faeces collected from rats from the laboratory colony.

In all experiments a cross over design with two periods was used in which each animal received the following dietary treatments: a control diet, without lactitol or lactulose syrup, and an experimental diet including one of these supplements. The animals were assigned to each of two groups by a random process. One group received the experimental diet in the first period and the control diet in the second; the other group was given the diets in the reverse order.

\section{DIETS}

The pigs were fed on a normal pig diet whereas the rats were given a semipurified diet based on casein and maize starch. ${ }^{13}$ The levels of lactulose and lactitol tested varied as shown in Table I. Lactitol was incorporated in the control diet for rats at the expense of maize starch at the level of $100 \mathrm{~g} / \mathrm{kg}$. For pigs, the same amount of lactitol $(100 \mathrm{~g})$ was added to each $\mathrm{kg}$ of control diet. Rats would not tolerate this amount of lactulose and thus $75 \mathrm{~g} / \mathrm{kg}$ was used. Pigs tolerated lactulose in the diet and animals were given as much as they would take while still producing semisolid faeces that could be collected separately from the urine.

\section{NUTRITIONAL BALANCE STUDIES}

During the balance periods complete collections of urine and faeces were made corresponding accurately to particular feeding periods. Urine was collected into $0.05 \mathrm{M}$ sulphuric acid to reduce losses of volatile nitrogenous substances. Samples were freeze dried before further processing..$^{13}$ All faeces and urine collections were analysed for nitrogen while the collections from the first group of conventional rats given lactulose were also analysed for $\alpha$-, $\varepsilon$-diaminopimelic acid.

\section{ANALYTICAL METHODS}

Nitrogen was determined by a micro-Kjeldahl method. To determine $\alpha$-, $\varepsilon$-diaminopimelic acid, protein hydrolysis was followed by purification of the acid on an anionic exchange resin and colorimetric estimation after reaction with ninhydrin. ${ }^{15}$

\section{STATISTICAL ANAL YSIS}

Data were subjected to standard analysis of variance for a cross over experiment ${ }^{16}$ and the standard errors of mean values presented are based on the residual error mean squares with $\mathrm{n}-2$ degrees of freedom where $\mathrm{n}$ is the number of animals.

The experiment with germ free animals was a cross over design in each environment. In the statistical analysis the error for comparing diets within an environment was based on residual variation within animals with six degrees of freedom, whereas for comparing environments within diets a pool of this error, and the error between animals within environments with five degrees of freedom, was used.

\section{Results}

The effects of including lactulose syrup and lactitol in the diets of pigs and rats are shown in Table I. The amount of nitrogen excreted per unit nitrogen consumed is given. This form of standardisation was done to remove the effect of differences in the protein content of the diet on nitrogen excretion thus facilitating comparison between species and with published data for humans.

Both supplements had consistently positive effects on the amount of nitrogen excreted in the faeces and negative effects on urinary nitrogen. The effects varied in degree, nitrogen in faeces

TABLE I Effect of experimental diets containing lactulose or lactitol on excretory losses of nitrogen in growing, conventional miniature pigs and hooded rats ( $m g / g N$ consumed)

\begin{tabular}{|c|c|c|c|c|c|c|c|}
\hline & \multirow[b]{2}{*}{$\begin{array}{l}\text { Concentration of } \\
\text { carbohydrate } \\
\text { (g/kg diet) }\end{array}$} & \multicolumn{3}{|l|}{ Faeces } & \multicolumn{3}{|l|}{ Urine } \\
\hline & & $\begin{array}{l}\text { Control } \\
\text { diet } \\
\text { (mean) }\end{array}$ & $\begin{array}{l}\text { Experimental } \\
\text { diet } \\
\text { (mean) }\end{array}$ & $\begin{array}{l}\text { Treatment } \\
\text { effect } \\
(\text { mean }(S E))\end{array}$ & $\begin{array}{l}\text { Control } \\
\text { diet } \\
\text { (mean) }\end{array}$ & $\begin{array}{l}\text { Experimental } \\
\text { diet } \\
\text { (mean) }\end{array}$ & $\begin{array}{l}\text { Treatment } \\
\text { effect } \\
(\text { mean }(S E))\end{array}$ \\
\hline \multicolumn{8}{|l|}{ Lactulose: } \\
\hline Miniature pig & $186-310$ & 114 & 191 & $+77(17 \cdot 5)^{\star}$ & 485 & 320 & $-165(59)^{\star}$ \\
\hline $\begin{array}{l}\text { Hooded rat } \\
\text { Lactitol: }\end{array}$ & Lactitol: & 114 & 161 & $+47(12 \cdot 1)^{\star}$ & 450 & 400 & $-50(18)^{\star}$ \\
\hline Miniature pig & 91 & 103 & 137 & $+34(8 \cdot 4)^{\star}$ & 490 & 455 & $-35(35)(\mathrm{NS})$ \\
\hline Hooded rat & 100 & 78 & 143 & $+65(9 \cdot 3)^{\star \star \star}$ & 600 & 510 & $-90(35)^{\star}$ \\
\hline
\end{tabular}

Mean urine values are rounded to nearest 5 , SEs rounded to nearest whole number. Carbohydrate added to control diet formulation given to miniature pigs. Carbohydrate incorporated into control diet formula given to rats at expense of maize starch. Six animals per diet except that 12 rats were used for lactitol. ${ }^{\star} \mathrm{p}<0 \cdot 05 ;{ }^{\star \star} \mathrm{p}<0 \cdot 001 ; \mathrm{NS}=\mathrm{p}>0.05$. 
TABLE II Effect of incorporating lactulose in the diet of growing, conventional hooded rats on the amount of $\alpha-, \varepsilon-$ diaminopimelic acid excreted in the faeces (Lactulose was incorporated in the control diet formula at the expense of maize starch at a level of $75 \mathrm{~g} / \mathrm{kg}$ )

\begin{tabular}{llll}
\hline & $\begin{array}{l}\text { Control } \\
\text { diet } \\
\text { (mean) }\end{array}$ & $\begin{array}{l}\text { Experimental } \\
\text { diet } \\
(\text { mean })\end{array}$ & $\begin{array}{l}\text { Treatment } \\
\text { effect } \\
(\text { mean }(S E))\end{array}$ \\
\hline Concentration $(\mathrm{mg} / \mathrm{g})$ & $0 \cdot 26$ & $1 \cdot 24$ & $0.98(0 \cdot 266)^{\star}$ \\
Total per day $(\mathrm{mg})$ & 0.65 & $4 \cdot 11$ & $3.46(0 \cdot 845)^{\star}$ \\
\hline
\end{tabular}

Six animals per diet. ${ }^{\star} \mathrm{p}<0 \cdot 05$.

being increased by $33 \%$ to $83 \%$, nitrogen in the urine being reduced by $7 \%$ to $34 \%$. All effects were significant apart from lactitol on urinary nitrogen in the miniature pig.

Table II shows the amounts of the bacterial amino acid $\alpha$-, $\varepsilon$-diaminopimelic acid in the faeces of rats on the control and the lactulose containing diets. With lactulose syrup in the diet the concentration in the faeces was about five times greater, and the total amount excreted was increased about six times compared with the control value.

In an experiment on germ free and conventional rats the effects of adding lactulose syrup to the diet of the conventional animals (shown in Table III) were similar to those previously observed (Table I), though the absolute values were higher. In the germ free rats, however, the effect on faecal nitrogen was completely reversed and a significant interaction between diet and environment was clearly established. In contrast, lactulose syrup had no effect on the nitrogen excreted in the urine by germ free animals.

\section{Discussion}

Currently the standard treatment for portosystemic encephalopathy is $100 \mathrm{~g}$ lactulose/day, or roughly $160 \mathrm{~g} / \mathrm{kg}$ of food dry matter. Our criterion for giving rats and pigs the doses used in these studies was the same as a doctor's - that is, maximum intake without precipitating diarrhoea. The amount given varied from 160 to 310 $\mathrm{g} / \mathrm{kg}$ of dry matter or up to twice the amount a patient may consume. The maximum dose we used is not vastly greater than the human dose and appeared to be physiologically equivalent. Unfortunately, lactulose has been available only as a sickly sweet syrup that is rather disliked. Nevertheless, it has proved reliably successful. A complete understanding of how it works is desirable since such knowledge could offer the prospect of developing suitable alternatives of greater acceptability to patients.
The first effect after consuming lactulose is probably catharsis, and indeed it is used successfully to treat constipation. Lactulose reaches the lower gut unchanged where it is metabolised by bacteria to short chain fatty acids ${ }^{17}$ with a consequent lowering of $\mathrm{pH}^{18}$ and thereby having a further cathartic effect. It would be expected that lactulose consumption would lead to considerable changes in the bacterial flora of the lower gut, but despite much study the picture is confused. ${ }^{2}$

The current work was done in normal healthy animals to clarify one aspect of the physiological effects of lactulose - that is, the effect on the excretion of the nitrogenous end products of protein digestion and metabolism. In our studies dietary supplements of both lactulose and lactitol increased the amount of nitrogen in the faeces and there was a concomitant, and generally greater, reduction in urinary nitrogen. In Weber's patients lactulose increased faecal nitrogen by $125 \mathrm{mg} / \mathrm{g}$ food nitrogen and urinary nitrogen was decreased by $85 \mathrm{mg} / \mathrm{g}$ food nitrogen. ${ }^{5}$ Thus in these respects the normal healthy rat and pig responded similarly to portosystemic encephalopathy patients.

Evidence that giving lactulose involved the gut flora was obtained by estimating faecal bacteria by measuring $\alpha$-, $\varepsilon$-diaminopimelic acid. This amino acid has been used as a marker for bacterial nitrogen in studies of ruminant nutrition $^{19}$ since it is present only in bacteria, though not in all species, and not in protozoa and plant material. (Rumen bacteria contained $4 \cdot 6$ mg $\alpha$-, $\varepsilon$-diaminopimelic acid/g dry cells. ${ }^{19}$ ) Giving lactulose syrup to rats led to a considerable increase in the amount of this amino acid excreted, suggesting an increase in the number of bacteria in the faeces. The ratio of $\alpha$-, $\varepsilon$-diaminopimelic acid to nitrogen in bacteria varies widely, however, and it is possible that a treatment effect could arise from an alteration in the composition of the bacterial flora rather than from a change in the total number of bacteria. Nevertheless, the effect observed was so pronounced that it seems likely that there was an increase in the bacterial content of the faeces. Recently, Weber and coworkers assessed the effect of lactulose on faecal material directly. ${ }^{20}$ They applied a physical method of quantitative separation to patients' faeces and showed that lactulose increased both the bacterial nitrogen and, surprisingly, the non-bacterial soluble nitrogen components of the excreta. The effect on the bacteria confirms our results, though the experiments are not directly comparable due to the possible effects of the different diet types used.

TABLE III Effect of incorporating lactulose in the diet of growing, germ free, and conventional hooded rats on excretory losses of nitrogen ( $\mathrm{mg} / \mathrm{g} N$ consumed) (Lactulose was incorporated in the control diet formula at the expense of maize starch at a level of $75 \mathrm{~g} / \mathrm{kg})$

\begin{tabular}{|c|c|c|c|c|c|c|}
\hline & \multicolumn{3}{|l|}{ Faeces } & \multicolumn{3}{|l|}{ Urine } \\
\hline & $\begin{array}{l}\text { Control diet } \\
\text { (mean) }\end{array}$ & $\begin{array}{l}\text { Experimental } \\
\text { diet (mean) }\end{array}$ & $\begin{array}{l}\text { Treatment effect } \\
(\text { mean }(S E))\end{array}$ & $\begin{array}{l}\text { Control diet } \\
\text { (mean) }\end{array}$ & $\begin{array}{l}\text { Experimental } \\
\text { diet (mean) }\end{array}$ & $\begin{array}{l}\text { Treatment effect } \\
(\text { mean }(S E))\end{array}$ \\
\hline $\begin{array}{l}\text { Germ free } \\
\text { Conventional } \\
\text { Environment effect (SE) }\end{array}$ & $\begin{array}{l}217 \\
163 \\
-54(18 \cdot 3)^{\star}\end{array}$ & $\begin{array}{l}140 \\
208 \\
+68(18 \cdot 3)^{\star \star}\end{array}$ & $\begin{array}{l}-77(14 \cdot 7)^{\star \star} \\
+45(14 \cdot 7)^{\star} \\
+122(20 \cdot 8)^{\star \star}\end{array}$ & $\begin{array}{l}600 \\
630 \\
+30(40)(\mathrm{NS})\end{array}$ & $\begin{array}{l}570 \\
505 \\
-65(40)(N S)\end{array}$ & $\begin{array}{c}-30(20)(\mathrm{NS}) \\
-125(20)(\mathrm{NS}) \\
-95(28)^{\star}\end{array}$ \\
\hline
\end{tabular}

Mean values rounded to nearest 5 , SE rounded to nearest whole number. Four animals per diet.

${ }^{\star} \mathrm{p}<0.05 ;{ }^{\star \star} \mathrm{p}<0.01 ; \mathrm{NS}=\mathrm{p}>0.05$. 
The experiment with germ free rats provided further support for the involvement of the gut flora. It sould be pointed out, however, that there are differences between germ free and conventional animals which should be borne in mind in interpreting comparative results. Most importantly, there is the peculiar enlargement of the caecum and lower gut and the related physiological characteristics of germ free rodents. Differences in the efficiency of protein utilisation have been reported before, and we found that germ free rats on the control diet lost about a third more nitrogen than conventional rats. Similar observations, of a $22 \%$ increase $^{21}$ and of a $20-50 \%$ increase ( $Z$ Ofuya $e t a l$, personal communication) have been made; these effects may be due to the absence of the deaminating activity of bacteria in the germ free animals. In contrast to the effect of lactulose in conventional animals this treatment caused an appreciable decrease in faecal nitrogen in germ free rats, suggesting the possibility of some counteraction of the effect of the lack of a gut flora. The absence of any positive effect on faecal nitrogen supports the idea that the effect of lactulose in conventional animals is mediated through the gut flora.

These results support the hypothesis that lactulose is effective in the treatment of portosystemic encephalopathy because it stimulates bacterial growth in the lower digestive tract. This conclusion may, however, be simplistic. The bacterial population in the gut is extremely complex in type and number so the result of any treatment is likely to be complicated. Our results do not exclude the possibility that other treatments that act by means of the gut flora, such as antibiotics, may bring additional benefit above that due to undigested carbohydrates such as lactulose. Antibiotics rarely remove all bacteria as is the case in the germ free animal, and in patients treated with appropriate antibiotics there will often remain scope for treatment with indigestible carbohydrates. The clinical evidence for additive effects of one such antibiotic, neomycin, and lactulose is equivocal..$^{22}$ The gut flora can differ substantially between individuals and so too does individual tolerance to substances like lactulose. It seems reasonable to suppose, however, that appropriate antibiotics may usefully supplement lactulose treatment when substantial numbers of 'harmful' bacteria are unaffected by treatment with lactulose or when the patient will not consume enough lactulose for complete control of the metabolic activity of the gut flora.

It seems that lactitol has a similar effect to lactulose syrup. Further work is required to confirm that these sugars act simply as energy sources for the growth of bacteria in the gut and do not have other specific actions that depend on their chemical structure.

We thank CCA Biochem BV, Gorinchem, Holland, for the gift of We thank CCA Biochem BV, Gorinchem, Holland, for the gift of the Dairy Trade Federation for the financial support of SPB

1 Bircher J, Muller J, Guggenheim P, Haemmerli UP Treatment of chronic portal-systemic encephalopathy with lactulose. Lancet 1966; i: 890-3.

2 Conn HO, Lieberthal MM. The hepatic coma syndrome and lactulose. London: Williams \& Wilkins, 1978

3 Mason VC, Palmer $R$. The influence of bacterial activity in the alimentary canal of rats on faecal nitrogen excretion. Acta Agriculturae Scandinavica 1973; 23: 141-50.

4 Dahlqvist A, Gryboskl JD. Inability of human small-intestina lactase to hydrolyse lactulose. Biochim Biophys Acta 1965; 110: 635-6.

5 Weber FL. The effect of lactulose on urea metabolism and nitrogen excretion in cirrhotic patients. Gastroenterology 1979; 77: 518-23.

6 Mason VC. An explanation of the effect of lactulose in the treatment of hepatic encephalopathy? Gastroenterology 1974 66: 1271

7 Rossi-Fanelli F, Cangiano C, Ceci F, et al. In: Conn HO Bircher J, eds. Hepatic encephalopathy: management with lactulose and related carbohydrates. East Lansing, Michigan: Medi-Ed Press, 1988

8 Lanthier PL, Morgan MY. Lactitol in the treatment of chronic hepatic encephalopathy: an open comparison with lactulose. Gut 1985; 26: 415-20.

9 Morgan MY, Hawley KE, Stambuk D. Lactitol versus lactulose in the treatment of chronic hepatic encephalopathy. A double-blind, randomised, cross-over study. pathy. A double-blind,

10 Morgan MY, Hawley KE. Lactitol vs. lactulose in the treatment of acute hepatic encephalopathy in cirrhotic treatment of acute hepatic encephatopathy in cirrhotic patients: a dou

11 Heredia D, Caballeria J, Arroya V, Ravelli G, Rodes J. Lactitol versus lactulose in the treatment of acute porta systemic encephalopathy (PSE). A controlled trial. F Hepatol 1987; 4: 293-8.

12 Heredia D, Teres J, Orlen N, Rodes J. Lactitol vs. lactulose in the treatment of chronic recurrent portal-systemic encephalopathy. F Hepatol 1988; 7: 106-10.

13 Bird SP, Hewitt D, Gurr MI. Energy values of lactitol and lactulose as determined with miniature pigs and growing lactulose as determined with miniature pigs and growing rats. Fourn.

14 Bird SP. Nutritional and metabolic effects of lactulose and lactitol. PhD thesis. Reading: University of Reading, 1986.

5 Smith RH, McAllan AB, Hewitt D, Lewis PE. Estimation of amounts of microbial and dietary nitrogen compounds entering the duodenum of cattle. Fournal of Agricultural Science 1978; 90: 557-68

16 Cochran WG, Cox GM. Experimental designs. 2nd ed. New York: Wiley, 1957.

17 Hoffman K, Mossel DA, Korus W, van de Kamer JH. Untersuchungen über die Wirkungsweise der Lactulose (B-Galactosido-Fructose) im Darm. Klin Wochenschr 1964; 42: $126-30$

18 Bown RL, Gibson JA, Sladen GE, Hicks B, Dawson AM. Effects of lactulose and other laxatives on ileal and colonic $\mathrm{pH}$ as measur.

19 Hutton KJ, Bailey FJ, Annison EF. Measurement of the bacterial nitrogen entering the duodenum of the ruminant using diaminopimelic acid as a marker. Br $\mathcal{F}$ Nutr 1971; 25: 165-73.

20 Weber FL, Banwell JG, Fresard KM, Cumings JH. Nitrogen in fecal bacterial, fiber, and soluble fractions of patients with cirrhosis: effects of lactulose and lactulose plus neomycin. f Lab Clin Med 1987; 110: 259-63.

21 Combe $E$, Pion $R$. Influence de l'axenie sur la composition en acidesamines des feces chez le rat et l'agneau. Annales de Biologie Animale, Biochemie et Biophysique 1977; 17: de Biolo

22 Weber FL. In: Conn HO, Bircher J, eds. Hepatic encephalopathy: management with lactulose and related carbohydrates. East Lansing, Michigan: Medi-Ed Press, 1988. 